\title{
8.13 Мовленнсва підготовка майбутніх педагогів до професійної діяльності в умовах нової української школи
}

\subsubsection{1. Професійне мовлення вчителя початкової школи як наукова проблема}

Перехід вітчизняної вищої освіти від парадигми викладання (передачі інформації) до парадигми навчання (формування компетенцій - потенціалу до дій) вносить корективи в підготовку майбутніх учителів початкової школи. Зокрема, орієнтація на всебічний розвиток мовлення студентів, посилення зв’язку змісту навчання з подальшою професійною діяльністю є підгрунтям їхньої фахової підготовки.

Життєві і професійні практики підтверджують значимість комунікативної компетентності майбутніх педагогів, які виразно прослідковуються у рекомендаціях втілення Зальзбурзьких принципів [764]. У контексті досліджуваної проблеми актуальні аналітичні міркування i висновки, презентовані в пораднику для вчителя “Нова українська школа”(Н. Бібік, 2017) [791]. Методологічні засади проблематики цієї публікації узгоджуються 3 концептуальними засадами реформування середньої освіти "Нова українська школа" [783]. Важливими комунікативними рисами майбутніх учителів початкової школи є вільне володіння державною мовою у будь-яких ситуаціях професійного спілкування, уміння планувати таку комунікацію, виховувати в собі ділові комунікативні якості та розвивати мовну стійкість. Досконалого рівня розвитку професійного мовлення студентів засобами української мови можна досягти лише за умови створення системної технології навчання мови в процесі фахової підготовки.

Цікаві міркування щодо компетентнісного підходу презентовано в наукових працях Т. Пантюк, М. Пантюка, I. Гамерської, Ю. Десиняк (2020) [793], Т. Сорочан (2018) [800]. У публікаціях [767, с. 14, с. 32, с.40] подано матеріали, які використовувалися для проведення аналогій у підходах вивчення освітніх компонентів підготовки майбутнього педагога. 
У вітчизняних і зарубіжних наукових працях $є$ різні підходи та тлумачення сутності змісту, обсягу, структури поняття «професійне мовлення»; думки про те, що немає потреби у формуванні професійного мовлення, оскільки «студенти володіють достатньою комунікативною компетенцією і це дає їм можливість вільно спілкуватися в суспільстві» [781, с. 43].

3 часу виникнення педагогіки як науки вимоги до вчительського мовлення неодноразово перебували в центрі уваги дослідників. Розробляючи теорію методів навчання, Я. Коменський приділяв особливу увагу словесним методам. Їх цінність він вбачав у тому, що вони активізують дитяче мислення й мовлення, підтримують увагу, сприяють успішному засвоєнню учнями зразків дій (читання, письмо, малювання тощо). Необхідною умовою реалізації всіх цих завдань $є$, на думку великого педагога, досконале вчительське мовлення. Саме на нього розраховував Я. Коменський, коли писав: «Нехай учитель змушує дітей наслідувати те, що він говорить, нехай він звертає увагу на те, як вони наслідують, і нехай того, хто помиляється, він відразу виправляє».

Творчий розвиток ідей видатного педагога минулого бачимо в численних працях К. Ушинського. Класифікуючи методи навчання, він зіставляв результативність використання вчителем бесіди й розповіді на уроці, віддаючи перевагу діалогові. При побудові запитань для бесіди вчений радить чітко продумувати їх зміст і логіку, ясно й зрозуміло формулювати. Педагог вважав, що бесіда має бути фронтальною.

К. Ушинським визначено основні вимоги до зв“язного викладу, а саме: усна розповідь вчителя має бути недовгою й обов“язково доступною для дитячого сприймання, а головна думка має легко визначатися учнями. Текст повідомлення, якщо він узятий з наукового джерела, повинен трансформуватися вчителем так, щоб учні відчували живе слово, а не «чужу фразу».

Звісно, заслугою К. Ушинського є глибоке усвідомлення ним ролі вчительського мовлення в навчально-виховному процесі, визначення основних вимог до нього, а також розробка конкретних методичних рекомендацій щодо користування бесідою й розповіддю як основними словесними методами 
навчання молодших школярів. Знання, на думку видатного вченого, треба доводити до свідомості учня, а для цього необхідна жива мова вчителя, його вміння захопити, зацікавити, змусити розмірковувати. Мовлення вчителя, його ерудиція, вміння вчасно навести приклад яскравого переконливого факту, скористатися прислів'ям, приказкою, іноді вдалим жартом, а там, де потрібно, показати, як досліджуване мовне явище застосовується на практиці.

Професійне мовлення вчителя початкової школи перебувало в центрі уваги послідовників К. Ушинського - М. Бунакова, В. Вахтерова, В. Водовозова, Д. Тихомирова та ін., які поділяли погляди видатного педагога щодо необхідності досконало володіти навчальним діалогом. Заслуговує на увагу їхня спроба визначити основні якості вчительського мовлення, які узагальнено можна подати так: доступність, варіативність, ясність, простота, точність, логічність, емоційність.

Про якості вчительського мовлення свого часу говорив і Л. Толстой. Спираючись на власні педагогічні спостереження, він зауважував: «Чим легше вчителю вчити, тим важче учням учитися. Чим важче вчителю, тим легше учням». Учений зазначає, що вчителеві необхідно суворо і вимогливо підходити до відбору лексичних засобів для повідомлення чи пояснення на уроці, уникати «незрозумілих слів,... знаходити слова простіші і доступніші».

Отже, аналіз поглядів видатних педагогів і методистів минулого дає підстави зробити висновки про те, що прогресивна наука завжди обстоювала думку про важливу соціальну значущість діяльності вчителя початкової школи і ставила високі вимоги до його підготовки - теоретичних знань та практичних умінь. На одному з перших місць було володіння професійним мовленням.

Надзвичайно великого значення надавав слову вчителя В. Сухомлинський: «У руках вихователя слово - такий же могутній засіб, як музичний інструмент в руках музиканта, як фарби в руках живописця, як різець i мармур в руках скульптора» [802]. Культура слова, за В. Сухомлинським, виховує емоційну культуру, яка впливає на загальну поведінку людини. Педагог прагнув того, щоб «це життєдайне джерело - багатство рідної мови - було відкрите для дітей 3 
перших кроків їхнього шкільного життя», домагався, щоб «діти відчували красу слова, дбали про його чистоту» [802].

В. Сухомлинський закликає вчителів бути надзвичайно обережними, «щоб слово не стало батогом, який, торкаючись ніжного тіла, обпалює, залишаючи на все життя грубі рубці. Слово оберігає душу... тільки тоді, коли воно правдиве i йде від душі вихователя, коли воно позбавлене фальші, упередженості...» [802].

Більшість рекомендацій стосовно вироблення цінних якостей вчительського мовлення не втратила свого значення і нині.

Пізніше різні аспекти проблеми культури вчительського мовлення висвітлювалися на сторінках численних монографій (Н. Бабич, В. Гриньова, А. Капська, Н. Кічук, А. Ліненко, С. Сисоєва та ін.), дисертаційних досліджень (А. Азарова, Д. Балдинюк, Л. Головата, Л. Дерев“янко, Л. Зінченко, О. Кретова, В. Каплінський, О. Попова, Л. Струганець, В. Усатий та ін.).

Не залишалися осторонь цієї проблеми й автори статей у науковометодичних фахових журналах (Н. Бабич, Л. Батюк, О. Біляєв, М. Васильєва, А. Коваль, Р. Колесникова, Я. Король, Т. Ладиженська, М. Лазарев, В. Мельничайко та ін.).

Аналіз праць свідчить про широту діапазону проблематики професійної підготовки вчителя початкової школи (О. Абдулліна, Є. Бєлозерцев, В. Беспалько,
С. Домбровський,
В. Кан-Калик,
Л. Коваль,
В. Козлова, А. Крамаренко, Н. Кузьміна та ін.). Окремі 3 них присвячено питанням готовності фахівця до викладання різних навчальних предметів у початковій ланці школи (С. Звєрева, Н. Істоміна, Л. Кейран, Ю. Колягін, М. Львов, А. Пишкало, В. Разумовський, А. Усова та ін.).

Вивчення наявної літератури дозволяє визначити основні напрямки проведення досліджень, а саме:

- розробка професіограми і кваліфікаційної характеристики вчителя
(Г. Михалевська,
Є. Осовський,
Л. Подимова,
В. Сластьонін,
Л. Спірін,
О. Щербаков та ін.); 
- дослідження проблеми формування особистості педагога в процесі його професійної підготовки (Т. Амельченко, Т. Ахмаєв, С. Баранов, Г. Волікова, В. Докучаєва та ін.);

- дослідження змісту, форм і методів засвоєння теоретичних знань і формування педагогічних умінь 3 окремих видів діяльності вчителя початкової школи (Н. Воскресенська, Т. Зацепіна, Л. Коваль, Н. Лаврова, М. Львов, Н. Максименко, А. Пишкало, Л. Стойлова, С. Тадіян, І. Шапошнікова та ін.); - забезпечення готовності студентів педвузу до розвитку творчої активності молодших школярів (Д. Іванова), педагогічного спілкування (О. Кіліченко, Г. Ковтун);

- 3`ясування умов формування монологічного мовлення майбутніх учителів початкових класів (М. Соловейчик, Н. Мартинович та ін.).

Розвиткові професійного мовлення студентів присвячені дослідження Л. Барановської， Г. Бондаренко， С. Вдовцової， Л. Головатої， І. Дроздової, О. Златів, Н. Івашкіної, О. Кретової, Л. Лучкіної, Т. Окуневич, Л. Струганець, Н. Тоцької та ін. Професійне мовлення вивчали науковці різних галузей (лінгвісти, психологи, соцолінгвісти, лінгводидакти тощо), тому й характеризують його, підкреслюючи саме ті особливості, які властиві конкретній науці або пов'язані з тим чи іншим видом професійної діяльності. Зокрема, у працях Н. Бабич, Ф. Бацевича, О. Біляєва, А. Богуш, Б. Головіна, О. Заболоцької, М. Ілляша, А. Коваль, Л. Мацько, Т. Ладиженської, Л. Паламар, М. Пентилюк, О. Пономарева, Г. Сагач, О. Семеног, Т. Симоненко, Л. Струганець, Н. Тоцької та ін. подані характеристики мовлення, сформованість яких є передумовою його дієвості, а отже, дає підстави вважати їх основою професійного мовлення. Чимало досліджень присвячено формуванню професійного мовлення студентів у процесі вивчення української мови, але вчені переконували, що однієї лінгвістичної підготовки для цього замало, необхідні спецкурси, дисципліни вільного вибору студентів, комплекс яких забезпечить вироблення необхідних умінь і навичок. 
Професійне мовлення - це спілкування певної групи людей, лексика яких спирається на професіоналізми відповідного фаху. Професіоналізмами вважаються слова, словосполучення або звороти, властиві певній групі людей, об’єднаних спільною діяльністю. Вони виконують важливу номінативнокомунікативну функцію, оскільки точно називають предмети, явища, процеси. Значна частина професіоналізмів з часом стає термінами, які позначають поняття певної галузі науки, культури тощо [775, с. 56-57]. Ми погоджуємося з думкою I. Дроздової про те, що одним 3 найважливіших показників професійного мовлення студентів має бути точність. Це пов'язано глибиною знань, фаховою та науковою ерудицією, знанням мови професії [777, с. 44].

Дослідники (Г. Апресян, Н. Бабич, Б. Головін, А. Коваль, Л. Мацько, М. Пентилюк та ін.) до комунікативних якостей мовлення, що визначають рівень професійного мовлення студентів, сприяють саморозвитку й самореалізації, формуванню фахової досконалості особистості, відносять такі: правильність (нормативність), логічність, ясність, чистоту, виразність, доречність, достатність, емоційність (експресивність). Учителеві початкової школи в процесі фахової підготовки слід набути на високому рівні усіх зазначених якостей. Зокрема, дотримання орфоепічних, акцентуаційних, морфологічних, синтаксичних норм і використання відповідних ритміко-інтонаційних моделей забезпечить передачу важливих смислових та емоційних відтінків висловлювань, стану і настрою мовця, його ставлення до предмета повідомлення i слухачів. Прагматична спрямованість мовлення, його впливовий ефект визначаються набором професійних компетентностей, якими володіє майбутній учитель початкової школи.

Учені намагалися обгрунтувати парадигму видів, форм та рівнів професійного мовлення. Так, під видами мовлення майбутніх учителів початкової школи розумітимемо різні аспекти його мовленнсвої діяльності, що виділяються залежно від характеру мовлення (внутрішнє/зовнішнє), способу організації мовлення (усне/писемне), міри активності (продуктивне/перцептивне) [765, с. 321]. 
Мовлення вчителя досліджувалося в зарубіжній і вітчизняній педагогіці, зокрема вимоги до нього визначені в працях Л. Толстого, К. Ушинського, В. Водовозова, М. Пентилюк, М. Стельмаховича, В. Сухомлинського та ін. Його розглядали в контексті комунікативного компонента педагогічної діяльності такі відомі педагоги й психологи: В. Кан-Калик, Н. Кузьміна, О. Леонтьєв, Л. Спірін та ін. Проблеми, пов'язані з оволодінням мовленням, висвітлювалися в працях, присвячених вивченню компонентів педагогічної техніки й педагогічного спілкування. Спинимося детальніше на характеристиці кожного аспекту формування професійного мовлення майбутніх учителів сучасної початкової школи.

Психологи переконують, що професійне спілкування обов'язково супроводжується певними змінами в стосунках, мотивах поведінки як з боку молодших школярів, так і самого педагога. Залежно від характеру взаємодії учні позитивно або негативно реагують на почуту інформацію, що, безумовно, не може не впливати на вчителя. У діалозі він дізнається про нові аспекти стосунків, що неминуче призводить до роздумів, узагальнення професійного досвіду, необхідності додаткової інформації тощо. Усе це, безумовно, спонукає вчених приділяти належну увагу стилям педагогічного спілкування, професійно значущим якостям педагога (любов і повага до дітей, громадянське почуття обов'язку, справедливість, довіра до молодших школярів тощо), перцептивногностичним умінням i навичкам, педагогічним здібностям, тренінгам спілкування, заняттям 3 техніки мовлення. Відзначаємо, що в контексті спілкування залишається не розробленою проблема професійного мовлення, його внутрішньої ланки, вдосконалення якої $є$ пріоритетним порівняно із зовнішнім. Відповідно психологами розроблена концепція професійного мовлення, складовою якого є внутрімовленнєва ланка, яка містить інформацію про специфіку, класифікацію основних мовленнєвих засобів, емпіричні дані про ступінь їх вираження в поєднанні з характеристикою сприйняття молодшими школярами, теоретичне обгрунтування понятійного апарату процесів говоріння й розуміння. 
Аналіз наукової літератури дозволив сформулювати основні положення, які забезпечать успішне розв’язання проблеми:

основний критерій ефективності мовлення - рівень глибини й повного розуміння слухачами;

професійне мовлення вчителя - єдність внутрімовленнєвої ланки і зовнішнього мовлення; причому перевага віддається внутрімовленнєвому компоненту, який визначає зміст висловлювання, його адекватність умовам взаємодіі;

професійне мовлення вчителя має за мету взаєморозуміння; важливою умовою iї досягнення $\epsilon$ знання про характер функціонування відповідних психічних механізмів;

- рефлексивне відношення до власного мовлення формується ефективніше, якщо оптимально поєднувати загальний і конкретний матеріал, які розкривають суть професійного мовлення [778, с. 16].

Ураховуючи те, що мовлення є важливим знаряддям діяльності для багатьох професій, особливу роль ми все ж таки відвели дослідженню мовленнєвої специфіки. У результаті аналізу наукових джерел констатуємо, що мовленню вчителя притаманні такі ж якості, як лекторському, акторському, але в кожній 3 цих професій йому відводиться своя роль. Професійне мовлення виконує досить унікальні функції, але характерне для конкретної діяльності їх відношення може визначити мовленнєву специфіку - інтенсифікувати розвиток певної групи мовленнєвих якостей. Оскільки відомі з них не піддавалися систематизації, на нашу думку, не завадило б визначити таку основу для впорядкування їх. Вивчення наукової літератури дозволило зробити висновок, що таким підгрунтям можуть бути образи, емоції й знаки, кожен 3 яких виконує відображувальну й регулятивну функції. Одні якості системи виявилися більше пов'язаними 3 образною (образність, мовне багатство, доступність для розуміння), інші - $з$ емоційною (емоційність, наказовість, тактовність), треті - зі знаковою (свідомість, інформативність, точність) сферами психіки. Крім того, особливе місце в цій системі відведено динамічності й непідготовленості, які 
характеризують мовлення й водночас є свого роду суб’єктивними умовами, що забезпечують оптимальну реалізацію зазначених вище груп якостей.

Вважаємо за доцільне спинитися на встановленні зв’язків між мовою і мисленням, оскільки, на нашу думку, вони відіграють важливу роль у формуванні вчительського мовлення. Цілком погоджуємося 3 думкою О. Леонтьєва про те, що мовленнєвий механізм складається з шести частин:

- механізму мотивації та ймовірного прогнозування мовленнєвої діяльності;

- механізму програмування мовленнєвої діяльності;
— $\quad$ механізму переходу від плану програмування до граматичносинтаксичної структури речення;

- механізму пошуку потрібного слова за семантичними й звуковими ознаками;

$$
\begin{aligned}
& \text { - } \quad \text { механізму моторного програмування до заповнення їі звуками; } \\
& \text { — } \quad \text { механізму забезпечення реального звучання мови }[788, \text { с. } 10] .
\end{aligned}
$$

Як зазначає Л. Паламар, існує два типи мовлення: розгорнуте і внутрішнє. Розгорнуте - це мовлення просте, яке характеризується спрощеним синтаксисом, мінімумом синтаксичних членувань.

Внутрішнє мовлення - це пошукове мислення, якому вчитель під час професійної підготовки прагне навчитися [792, с. 81].

Кваліфікувати мовлення як діяльність уможливлюють, по-перше, різні варіанти введення його в життєві ситуації (в одних мовлення виконує функцію діяльності, а в інших - виду діяльності), а, по-друге, характеристика джерел мотивації мовлення, що свідчить про активну діяльність людини у своїх прагненнях досягти певної мети.

Мовлення в системі діяльності може займати різне місце, зокрема, засобу планування мовних чи немовних дій, мовних висловів.

О. Леонтьєв, розглядаючи діяльність як засіб соціальної детермінації психіки людини, пропонує таку будову діяльності: 
○ «це те, що відрізняє одну діяльність від іншої. Воно складається 3 розмежування предметів, які називаються мотивами»;

○ у структуру діяльності входять їі складники - «дії». Вони розуміються як процес, підпорядкований свідомій меті, а способи здійснення мети - операції [786, c. 161].

Професійне мовлення - це процес та результат мовленнєвої діяльності, яка, крім реалізації загальних вимог до культурного мовлення, передбачає педагогічну цілеспрямованість, спирається на обумовлені нею розуміння i врахування причиново-наслідкових зв’язків під час добору та компонування мовних засобів і орієнтується на професійні умови, де вона реалізується, коли перебудовує чи закріплює виховні стосунки.

Безумовно, на будь-який з аспектів педагогічного мовлення впливають три фактори:

\section{- педагогічна діяльність; \\ - педагогічне спілкування; \\ - ова, яка обумовлює можливості й специфіку цієї діяльності.}

Оскільки мовлення — це процес говоріння, тобто користування мовою (як знаковою системою) кожною конкретною особистістю, то професійне мовлення вчителя - це процес, спрямований на оптимальне вирішення як конкретних педагогічних завдань, так і на досягнення мети виховання особистості учня загалом. Підставою для такого визначення можна вважати слова О. Леонтьєва про те, що проблема формування професійного мовлення має два аспекти: «...3 одного боку, слід відпрацьовувати мовленнєві навички, мовленнєві автоматизми, необхідні для будь-якого мовлення незалежно від його призначення та способу побудови; з іншого - формування мовленнєвих умінь, тобто саме ті, які роблять мовлення відповідним меті, придатні для вирішення певного завдання» [787, с. 75]. Саме цим, на нашу думку, професійне мовлення вчителя відрізняється від усіх інших типів мовлення, наприклад, мовлення інженера, науковця, лікаря тощо. Мета, на досягнення якої спрямований процес взаємодії, і визначає його специфіку. 
Основою формування мовленнєвої діяльності вчителя є обмін репліками, практична діяльність, осмислення власного мовлення й розуміння співбесідника.

Цілком співзвучне 3 нашими міркуваннями розуміння О. Леонтьєвим мовлення як діяльності. Кваліфікувати дозволяють, по-перше, різні варіанти введення мови в життєві ситуації, причому в одних мовлення виконує функцію діяльності, а в інших - ii виду; по-друге, характеристика джерел мотивації мовлення свідчить про активну діяльність людини у своїх прагненнях досягти певної мети [787, с. 77].

Мовлення в системі діяльності може займати різне місце, зокрема, i планування мовних і немовних дій, тобто формування плану дій у мовній формі.

О. Леонтьєв слушно пропонує розрізняти «внутрішнє мовлення», «внутрішнє програмування», «внутрішнє промовляння», «внутрішній вислів», бо спочатку вислів програмується, а потім реалізується в мовному коді. Механізми програмування такі: вибір слова; перехід від відібраного матеріалу до його реалізації; граматичне прогнозування; закріплення граматичних закономірностей.

Важливим стимулом вислову $\epsilon$ мовна інтенція, яка не ідентична семантичній стороні висловлювання, бо семантична сторона формується на поєднанні лексем, необхідних для висловлення думок. Мовна інтенція спонукає мовця до участі в спілкуванні.

Л. Виготський називав мовну інтенцію «відчуттям завдання», «туманним бажанням мовця висловитися» [771, с. 107]. Окрім того, вчений назвав такі факти, що формують мовну інтенцію: мотивація мовної діяльності; обставинна ситуація; попередній мовний досвід; завдання, яке необхідно реалізувати, ураховуючи вид мовлення та його форму.

У свою чергу В. Сухомлинський у багатьох своїх працях наголошував на ролі вчительського мовлення: «Кожне слово, яке звучить у стінах школи, має бути продуманим, мудрим, цілеспрямованим» [801, с. 140]. 
Для відомого психолога Л. Виготського в проблемі мислення і мовлення основним $€$ питання відношення думки і слова. Слово - єдність звуків і значення, а також усіх засобів, притаманних мовленню і мисленню загалом [771].

Як доказ того, що думки існують лише в мовленнєвій формі, у психологічній літературі стверджується: немає іншої форми існування думок, крім мовлення, оскільки тоді можна будо б говорити про наявність «оголених думок», не втілених у мовленнєвій формі.

Думки людини - це скорочені дії, які спираються на ті чи інші знакові опосередкування; а мовленнєві форма існування думки - це найбільш виправдана соціально контрольована форма думки, пристосована для трансляції в просторі і часі [766, с. 18].

Розуміння мовлення як певного виду мовленнєвої діяльності вперше було дано Л. Виготським і знайшло своє подальше розкриття в дослідженнях О. Леонтьєва. Мовленнєва діяльність починається мотивом і планом, a завершується результатом, досягненням поставленої мети.

Спосіб створення і формулювання думки за допомогою мови може суттєво змінюватися, перш за все, залежно від мети комунікації, тобто від того, кому адресоване висловлювання - собі чи співбесіднику. За умови адресування мовлення співбесіднику обов'язковою є його присутність. У кожному з названих випадків спосіб формування і формулювання думки виявляється по-різному, наприклад, внутрішньому і зовнішньому (усному чи писемному) мовленні.

Ф. Гоноболін у своїх працях виділяє такі якості вчительського мовлення:

- ті, які забезпечують його правильність (відповідність лексичним, акцентуаційним, граматичним нормам);

- такі, що обумовлюють дієвість мовлення, зокрема змістовність (ясність, простота, доступність), чітка система викладу, послідовність думок, дотримання поступовості в труднощах тощо;

- спрямованість мовлення на слухача, яке вимагає врахування його сприйняття і розуміння;

- емоційність, переконливість і навіювання [773]. 
Розвиваючи цю думку, відомий психолог і педагог I. Синиця у своїх працях неодноразово відзначав, що «слово - головна зброя вчителя». Крім того, тезу «яке мислення людини, таке i його мовлення» [799, с. 13-14] можна переформулювати так: «Яке мовлення у людини, таке його мислення».

У структурі інтелекту вчителя значна роль відведена внутрішньому мовленню, за допомогою якого відбувається логічна перебудова чуттєвих даних, їх усвідомлення і мотивація в певну систему понять і суджень.

Як свідчать наукові джерела, вчені по-різному розглядають поняття «професійне мовлення». Так, В. Наєр характеризує його як певну «зміну мовного регістра». Загалом мова (інструмент) залишається такою ж національною мовою, але в конкретних (професійних) умовах вона змістовно репродукується, стає залежно від галузі знань і предмета спілкування монотематичною, насичується спеціальними словами і виразами, використання яких передбачає такий же професіоналізм, тобто компетентність [790].

В. Даниленко відзначає, що в професіоналів конкретної галузі знань подібна «зміна регістрів» здійснюється природно й автоматично, однак у спілкуванні фахівців різних сфер діяльності механізм залучення мови зі спеціальною метою не спрацьовує автоматично, особливо тоді, коли сфери професійної діяльності достатньо далекі одна від іншої [776].

Дещо іншої думки притримується М. Грабовський, вважаючи, що важливим компонентом професійного мовленнєвого акту є адресат, партнер по комунікації. Психологічні й соціальні особливості статусу мовця та адресата дозволили вченому виокремити як самостійні інтерпрофесійну та інтрапрофесійну комунікації. «Інтерпрофесійна комунікація $є$ мовленнєвим актами, у яких професійні ролі комунікантів не збігаються» [775]. Прикладом може слугувати спілкування типу лікар - пацієнт, учитель - батьки. «Інтрапрофесійна комунікація здійснюється в межах певної соціально-професійності спільноти» [775, с. 15]. Хоча, як зауважує дослідник, слід ураховувати, що комунікація за моделлю «спеціаліст - спеціаліст» неоднорідна, вона включає і однодисциплінарні, і різнодисциплінарні напрями. 
Ми погоджуємося 3 думкою вчених про те, що в професійній сфері спілкування фахівець користується усталеними знаннями засобами спеціальної мови. Розглядаючи цю особливість комунікації, розроблені своєрідні моделі професійних мов, які складаються, по-перше, з наукової мови; професійної розмовної мови, яка включає, перш за все, певні професійні слова i словосполучення і слугує переважно для повсякденного спілкування людей, які працюють у певній галузі.

Нам імпонує таке визначення професійного мовлення: «Це мовна комунікація, яка здійснюється в процесі професійної діяльності». Тому ми розумітимемо під професійним мовленням вчителя початкової школи будь-яке мовне спілкування, що здійснюється під час професійної діяльності педагога [775].

Отже, незважаючи на різноманітність підходів до визначення поняття «професійне мовлення», суть їх збігається в одному: професійне мовлення - це, перш за все, комунікація, яка здійснюється за допомогою спеціальних професійно маркованих засобів мови. Основою всіх визначень є компоненти, які характеризують професійне мовлення:

- установка на специфічне спілкування;

- орієнтація на процес безпосередньої комунікації;

- зв'язок професійного мовлення з мовною системою;

- відповідність професійних висловлювань різним стилям і жанрам мови.

Фахівці різних галузей, здійснюючи свою професійну діяльність, використовують, окрім мовлення, різноманітні засоби: інструменти, прилади, машини тощо. Професія педагога - одна серед небагатьох, де слово - єдиний дієвий засіб фахової самореалізації, що вимагає досконалого володіння мовленням. Як засіб передачі інформації професійне мовлення вчителя в той же час $є$ інструментом, за допомогою якого розв’язуються завдання навчання i виховання. Тому будь-яке педагогічне спілкування передбачає словесну взаємодію між учителем та учнями, що визначає особливий підхід до вибору інформації та її інтерпретації. Таким чином, головне в мовленні вчителя - якість 
його змісту, що забезпечує високі результати педагогічної діяльності, а згодом і педагогічну майстерність.

Суспільство висуває такі вимоги до мовлення вчителя початкової школи:

- визначати зміст і форму передачі думок відповідно до рівня розвитку молодших школярів (мислення, загальна та мовна культура);

- дотримуватися законів мови під час спілкування;

- ураховувати мовленнєві і психологічні закони до успішного досягнення мети спілкування.

Професійне мовлення вчителя початкової школи передбачає індивідуалізацію й диференціацію педагогічного впливу у зв'язку з різними функціями і конкретними діями педагога, що дозволяють йому гнучко й адекватно до ситуації реалізувати професійні позиції й ролі.

Управлінський потенціал мовленнєвого впливу розширюється на різних спілкування (з молодшими школярами, колегами, батьками), що забезпечує різноманітність наукових досліджень.

Слід відзначити, на нашу думку, серед інших концепцію М. Вашуленка щодо адаптації професійного мовлення вчителя початкової школи, пов’язаної 3 побудовою синонімічних рядів у дидактичному мовленні шляхом гнучкості, партнерства й динамічності структури та змісту мовленнєвих дій комунікативного впливу. Це дозволяє педагогові повноцінно реалізувати навчальні функції залежно від освітньої мети, типу уроку, можливостей педагога й підготовленості учнів.

Усе зазначене вище переконливо доводить необхідність особливої уваги до мовленнєвої підготовки майбутнього вчителя початкової школи. До умов ефективності цього процесу у вищій школі, а згодом і досягнення необхідного рівня професійного мовлення слід віднести такі:

- пріоритет особистісного навчання, коли педагогічна технологія розглядається як засіб самовираження суб'єкта в професії;

- організація повноцінної дидактичного впливу на всебічний розвиток особистості студентів; 
- діалогізація й рефлективність в організації педагогічної взаємодії суб’ єктів освітнього процесу на основі співробітництва;

- проблемність і творчість у засвоєнні змісту освіти й цілеспрямоване оволодіння технологіями спілкування;

- етапи професійної підготовки реалізуються в логіці становлення комунікативної програми педагога: вплив, взаємовплив, взаємодія;

- акцентування уваги на вміннях педагога гнучко перебудовувати позиції та ролі в спілкуванні, адекватно ситуації діяти з позиції об'єкта й суб'єкта.

Як свідчить досвід викладацької роботи, випускники педагогічних факультетів і вчителі початкової школи мають труднощі під час спілкування 3 молодшими школярами. Це відбувається найчастіше тоді, коли учні порушують дисципліну на уроці, оскільки вчитель не приділяє належної уваги залученню дітей до співпраці; порушення дисципліни молодшими школярами на уроці та перервах; проявах дитячої заздрості тощо.

Неправильна етично-педагогічна поведінка вчителя може спровокувати виникнення конфліктів. На основі зазначеного вище можна виокремити такі помилкові дії вчителя:

- маніпулювання сприйняттям ситуації, що свідчить про неправильне усвідомлення чи викривлення фактів. Про таке сприйняття ситуації вчителем свідчать його фрази: «Ти ніколи не виконуєш домашні завдання», «Ти завжди забуваєш свій щзоденник дома», «У твоєму диктанті безліч помилок» тощо. Категоричність висловлювань посилює їх негативний зміст, викликає у вихованця образу, бажання помститися, а головне зневіру у власні можливості. У результаті таких дій вчитель важко спрогнозувати ситуацію, але точно можна стверджувати, що вона буде діаметрально протилежною очікуваній;

- актуалізація неприємних ситуацій, коли вчитель нагадує учневі про минулі проблеми, які ще досить болісні для нього. Позбавлені будь-якого виховного впливу такі фрази вчителя: «Я думала. Що цее був поодинокий випадок, а, виявлясться, це твій характер», «Я тебе захищала від однокласників, а тепер 
розумію, щуо цього не варто було робити» тощо руйнують особистість, на підсвідомому рівні поновлюють негативні відчуття;

- безпосереднє протиставлення типове для ситуацій, коли педагог намагається продемонструвати свою перевагу, але робить це, принижуючи гідність вихованців, їхнє право на самостійність і самовизначення. Така позиція завуальована за словами: «Я вчитель, а ви - тільки учні», «Я людина доросла, тому краще знаю» тощо;

- різні погляди виникають і тоді, коли оцінка за знання базується, перш за все, на оцінці поведінки або занижується без будь-яких пояснень вчителем.

Отже, вчитель початкової школи не повинен припускатися етикопедагогічних помилок у спілкуванні з учнями, оскільки такі дії закріплюються на рівні свідомості, негативно впливаючи на професійну кар'єру, формування стратегії педагогічної діяльності загалом і спілкування зокрема.

В умовах особистісно-орієнтованого навчання виникає необхідність в основу критеріїв ефективної педагогічної діяльності ввести не тільки оцінки успіхів у навчанні дитини, а й відповідні виміри зусиль педагога щодо мотивації цієї діяльності, педагогічної культури, професійного мовлення.

Ефективність формування професійного мовлення майбутніх учителів початкової школи суттєво залежить від організаційних форм навчальної роботи у вищій школі. Основними на сьогодні є лекції; практичні, семінарські, лабораторні заняття; спецкурси; педагогічна практика, консультації; контрольні, курсові, дипломні та магістерські роботи. Особливий вплив на вироблення професійного мовлення, на нашу думку, має педагогічна практика і спецкурси та спецсемінари (дисципліни вільного вибору студента), які передбачають завдання, виконання яких забезпечить готовність педагогів до професійного спілкування. 


\subsubsection{2. Удосконалення мовленнсвих умінь майбутніх педагогів як} основа готовності їх до професійної діяльності в умовах Нової української школи

На основі аналізу наукових джерел (психологічних, лінгвістичних, психолінгвістичних) та власного викладацького досвіду ми запропонували здобувачам першого (бакалаврського) рівня вищої освіти освітньо-професійної програми 013 Початкова освіта факультету психолого-педагогічної освіти та мистецтв Бердянського державного педагогічного університету вибірковий освітній компонент «Професійне мовлення майбутніх учителів початкової школи» [795]. Він сприятиме вдосконаленню вчительського мовлення в процесі професійної підготовки майбутніх учителів початкової школи, а саме тих умінь і навичок, які сприятимуть повноцінному спілкуванню з учнями. Дисципліна передбачає 3 кредити СКТС, тобто 6 змістових модулів.

На лекціях ще раз наголошуємо на тому, що професійне спілкування вчителя початкової школи з учнями - це багатоаспектне педагогічне явище, яке забезпечує результативний процес організації взаємодії та взаєморозуміння між учасниками його учасниками. Зміст i характер педагогічного спілкування вчителя початкової школи відрізняється високим рівнем довіри між суб'єктами взаємодії; динамічністю характеру стосунків; урахуванням вікової та індивідуальної диференціації у взаємовідносинах. Педагогічне спілкування впливає на стан і характер комунікації молодших школярів між собою та іншими однолітками і старшими.

Крім того, на нашу думку, майбутнім учителям початкової школи не завадить нагадати, що на ефективність педагогічного спілкування впливає врахування соціальної значущості педагогічної професії; актуальними потребами молодших школярів у спілкуванні, пов’язаними 3 їх віковими особливостями розвитку; потенційними можливостями навчальних дисциплін початкової школи, визначеними Державним стандартом початкової загальної освіти, особливостями впровадження ідей Концепції НУШ. 
На практичних заняттях основну увагу зосереджуємо на формуванні в майбутніх учителів початкової школи вмінь, які забезпечать повноцінне професійне спілкування з учнями:

на етапі моделювання комунікативної взаємодії педагога 3 дітьми він має володіти такими вміннями: вибирати найбільш доцільний щодо класу загалом і кожного учня зокрема спосіб поведінки й спілкування, який підготував би молодших школярів до сприйняття інформації; правильно планувати своє мовлення (тобто зміст самого повідомлення), добирати необхідні засоби для його корекції (тон, лексику тощо);

на етапі організації безпосереднього спілкування 3 учнями початкової школи педагогові необхідні такі вміння: налаштовувати дітей на спілкування, привертати їхню увагу, інтерес до предмета, який вивчається; оптимально побудувати власне мовлення відповідно до психологічних особливостей молодших школярів;

на етапі управління педагогічним спілкуванням педагог застосовує уміння: розподіляти і підтримувати увагу учасників взаємодії; цілеспрямовано підтримувати спілкування застосуванням елементів бесіди, риторичних питань;

на етапі аналізу проведеної системи спілкування і моделювання подальшої комунікації вчителеві потрібний комплекс таких умінь: аналізувати вчинки i мовленнєву поведінку молодших школярів; вносити необхідні корективи у процес взаємодії тощо.

Крім того, потенційними можливостями практичних занять з вибіркового освітнього компонента «Професійне мовлення майбутніх учителів початкової школи» для формування вмінь студентів $\epsilon$ :

реалізація комунікативного підходу, а саме особистісноорієнтованого навчання, яке передбачає толерантне ставлення до них, створення позитивного емоційного настрою; надання зразків мовленнєвої взаємодії учителя початкової школи та учнів; набуття досвіду мовленнєвого партнерства; 
організація занять 3 урахуванням прагматичного, когнітивного i педагогічного компонентів, які визначають зміст i характер комунікації, роботу з різними видами інформації;

навчання техніці спілкування, яка базується на використанні слухання і виголошування (монологічна та діалогічна форми мовлення) текстів як засобу формування педагогічного спілкування майбутніх учителів початкової школи.

На практичних заняттях студенти поглиблюють свої знання про техніку спілкування, яка, на нашу думку, відіграє важливу роль в ефективності взаємодії вчителя початкової школи з учнями. Зокрема майбутні вчителі початкової школи визначають техніку спілкування як сукупність умінь, навичок, прийомів, які дозволяють управляти педагогічним процесом. Комплекс можна поділи на дві групи компонентів:

ті, які пов'язані 3 умінням педагога керувати своєю поведінкою (мовлення, міміка, пантоміміка, вираження своїх емоцій, увага, спостережливість тощо);

уміння впливати на особистість і колектив.

На практичних заняттях майбутні вчителі мали змогу попрацювати над формуванням блоків техніки спілкування:

звертання (нейтральне, ніжне, раціональне, жартівливе, абсурдне, суворе);

ступінь причиновості (ігнорування етикету, коректність, люб’язність, делікатність, тактовність);

стиль поведінки (суто формальний, неформальний, простий); вираження почуттів (перебільшене, вільне, стримане);

мовлення: а) дикція (коректна, вільна); б) діалогізація (симетрія у спілкуванні, асиметрія в бік учня, асиметрія в бік учителя); в) жестикуляція (помірна, надмірна, відчайдушна); г) мовлення (правильне, літературне, народне); г) стиль мовлення (науково-навчальний, лаконічний, патетичний, риторичний). 
Контрольний зріз, а також анкетування студентів після проведення занять 3 вибіркового освітнього компонента «Професійне мовлення вчителя початкової школи» і виробничої практики в початковій школі дозволили визначити педагогічні умови, які забезпечать ефективність педагогічного спілкування 3 молодшими школярами:

організаційне перетворення занять зі студентами 3 використанням методів і прийомів, спрямованих на зміну форм, змісту, характеру діяльності і спілкування учасників педагогічної взаємодії;

провідна роль викладача під час організації суб'єктсуб’єктної взаємодії зі студентами, яка забезпечує трансляцію цілісного ставлення до партнерів по спілкуванню;

усвідомлення майбутніми вчителями початкової школи значущості умінь, які забезпечать успішне професійне спілкування з учнями, що стимулюватиме формуванню такими вміннями;

збагачення власного комунікативного досвіду студентів за рахунок реалізації взаємозв'язку ділового і дружнього спілкування на заняттях.

Важко переоцінити й значення праць 3 культури мовлення для формування іiї в майбутніх учителів початкової школи. Адже вони мають ознайомити учнів із законами і правилами мови, дати перші уявлення про «хороше і правильне» мовлення, навчити читати й розуміти художні тексти, сформувати основу писемного мовлення. Усе це може забезпечити лише авторитетний педагог, який є взірцем для наслідування молодшими школярами.

На жаль, рівень мовленнєвої культури майбутніх і молодих учителів початкової школи, як свідчать анкетні дані, щоденники спостережень студентівпрактикантів, конспекти уроків та позакласних заходів тощо, гальмує якісне педагогічне спілкування з учнями і батьками. Протягом останніх 5 років ми спостерігали й аналізували мовлення студентів денної й заочної форм навчання, проводили спеціальні зрізи, вивчали типові й індивідуальні помилки й недоліки, щоб у процесі подальшої роботи над формуванням професійного мовлення враховувати їх. Окрім того, ми зробили такі висновки: 
1. Формування професійного мовлення майбутніх учителів початкової школи слід розглядати як процес оволодіння комплексом узагальнених мовленнєвих умінь i навичок, що забезпечать створення ефективних усних і письмових текстів з урахуванням мети, завдань і суб’єктів комунікації.

Зважаючи на універсальний характер узагальнених мовленнєвих умінь і навичок, що забезпечують професійне мовлення учителів початкової школи, під час визначення змісту роботи над його формуванням у процесі фахової підготовки необхідна конкретизація. Здійснювати їі доцільно на основі визначення актуальних соціальних ролей (студента і вчителя початкової школи) і кінцевої мети вищої педагогічної освіти, яка передбачає комплекс компетентностей педагога, де комунікативна є однією з основних.

3. Формування професійного мовлення майбутніх учителів початкової школи буде ефективним, якщо максимально реалізувати міжпредметні зв’язки лінгвістичних і психолого-педагогічних дисциплін, які сприятимуть виробленню компонентів мовленнєвої культури; забезпечити наявність зразкового мовленнєвого середовища і єдиних вимог до мовлення впродовж усього періоду навчання; підгрунтям вироблення умінь і навичок буде теоретичне осмислення законів мови і мовлення; пріоритетними в процесі навчання обрати комунікативно-діяльнісний, особистісно-орієнтований та індивідуальний підходи.

Найбільші труднощі виникли під час створення зразкового мовленнєвого середовища і забезпечення єдиних вимог до мовлення студентів. Це можна пояснити, по-перше, тим, що частина здобувачів вищої освіти послуговується російською мовою в повсякденному житті, ураховуючи зрусифікованість регіону; по-друге, мало свій вплив явище білінгвізму. Звичайно, це, з одного боку, знизило ефективність роботи, а 3 іншого, дозволило переконатися на практиці в іï значущості.

Для того, щоб об’єктивно оцінити професійне мовлення майбутніх учителів початкової школи, використовували методи, традиційні для наукового 
дослідження: спостереження, різноаспектний аналіз усного (відеозаписи уроків студентів-практикантів) й писемного мовлення (твори на різні теми, есе, конспекти уроків, щоденник спостережень, реферати, доповіді тощо), анкетування першокурсників і випускників. Судячи 3 того, що критично оцінюють власне мовлення випускники, називаючи його «далеким від взірцевого», проблема формування професійного мовлення майбутніх педагогів не вирішується під час їхньої фахової підготовки. Тому, уточнюючи запитання, адресоване випускникам «З якими мовленнєвими труднощами Ви зіткнулись під час педагогічної практики?», ми 3‘ясували: майбутнім учителям початкової школи найбільше бракувало вмінь точно формулювати думки, доступно викладати матеріал (особливо той, який вивчався ними у процесі навчання в 3ВО), тобто провести трансформацію навчального матеріалу відповідно до вікових особливостей молодших школярів, логічно викладати думки. Це свідчить про недосконалість мовленнєвої підготовки здобувачів вищої освіти та недостатність її професійного спрямування.

Отже, аналіз досліджуваного матеріалу дозволив зробити висновок про те, що професійне мовлення майбутніх учителів початкової школи потребує вдосконалення. Так, у конспектах уроків і виховних справ студенти денної й заочної форм (а це вчителі початкової школи) припускаються на трьох сторінках у середньому 5-7 орфографічних і пунктуаційних помилок; 6 мовленнєвих недоліків; в усних і письмових текстах часто немає плану й порушена послідовність викладу думок, часті тавтологія та мовленнєві штампи; неправильно вживаються слова іншомовного походження, терміни. Звичайно, таке мовлення важко назвати взірцевим, тому під час професійної підготовки майбутніх учителів початкової школи варто цілеспрямовано формувати їхню мовленнєву компетентність.

Такі завдання вимагали розглядати професійне мовлення як об'єкт педагогічної роботи й конкретизації мовленнєвих умінь i навичок, які забезпечать комунікативну компетентність учителя початкової школи. При цьому ми враховували психолінгвістичний аспект породження й сприйняття 
мовленнєвого висловлювання. Зокрема, ураховувалася теорія мовленнєвої діяльності, яка дозволяє розглядати мовлення як сукупність дій, об’єднаних певною метою й підпорядкованих діяльності. Кожна така дія складається 3 окремих операцій і є різновидом інтелектуального акту, який включає 4 етапи: орієнтування, планування, реалізацію і контроль.

Не завадить здобувачам вищої освіти усвідомити й те, що здатність здійснювати мовленнєву дію згідно з оптимальними параметрами називається мовленнєвим умінням, а здатність здійснювати оптимальним способом ту чи іншу операцію - мовленнєвою навичкою. Як правило, навички забезпечують технічний і граматичний аспект мовлення й характеризуються автоматизмом; уміння мають творчий характер, передбачають свідоме й гнучке використання навичок, ураховуючи мету, завдання й адресата спілкування.

Спираючись на етапи мовленнєвої дії (орієнтування, планування, реалізація, контроль), ми визначили ті вміння i навички, які забезпечать формування професійного (усного і писемного) мовлення майбутніх учителів початкової школи. При цьому бралося до уваги те, орієнтирами виступали мета і зміст вищої педагогічної освіти, необхідність усвідомлення ролі вчителя початкової школи.

Перелік умінь і навичок професійного мовлення свідчив про те, що сформувати їх лише на заняттях 3 однієї або кількох окремих навчальних дисциплін не можливо. Зрозуміло, що робота над виробленням умінь і навичок професійного мовлення, які $\epsilon$ частиною фахової компетентності вчителя початкової школи, відкриває реальні можливості міжпредметних зв’язків сучасної вищої школи. Тлумачення професійного мовлення як найважливішого складника фахової компетентності майбутнього вчителя початкової школи, яке забезпечує всі сфери педагогічного спілкування, дозволяє стверджувати, що саме воно є фундаментом його професійної майстерності. Відповідно й процес формування професійного мовлення здобувачів вищої освіти доцільно організувати так, щоб спочатку засвоїлися універсальні знання мови й мовлення (лінгвістичні дисципліни), а потім на їх основі створювалися багатокомпонентні педагогічні вміння (психолого-педагогічні, методичні дисципліни, спецкурси). 
Здійснення наступності в цьому може реально сприяти усвідомленню майбутніми вчителями об'єктивного взаємозв’язку між лінгводидактичними й психолого-педагогічними дисциплінами, що, у свою чергу, сприятиме педагогізації перших і результативності других.

Оскільки такий підхід не суперечить загальній логіці здійснення фахової підготовки в закладах вищої освіти, вважали за потрібне, вивчивши навчальні програми традиційних для освітньо-професійних програм 013 Початкова освіта освітніх компонентів, поділити процес формування професійного мовлення майбутніх учителів початкової школи на три етапи: початковий, основний, заключний.

На початковому етапі здобувачі вищої освіти систематизують знання понять «культура мовлення»; знайомляться з вимогами, які висуваються до мовлення майбутніх учителів початкової школи; засвоюють норми сучасної української літературної мови. Окрім того, визначається вихідний рівень володіння необхідними уміннями й навичками усного та писемного мовлення, встановлюються типові й індивідуальні недоліки мовленнєвого розвитку кожного здобувача, здійснюється корекція; удосконалюються вміння виразного читання, ораторської майстерності, складання усних і письмових текстів різних стилів, але особливо акцентується увага на науковому стилі і його під стилях (реферат, доповідь, презентація, повідомлення, усна відповідь, конспект тощо). Важливим завданням, яке ставили на цьому етапі, - сформувати в майбутніх учителів початкової школи адекватну оцінку свого усного і писемного мовлення та усіляке заохочення їх у процесі вироблення відповідних умінь і навичок.

Другий етап передбачав відпрацювання й професіоналізацію мовленнєвих умінь і навичок. Спираючись на знання, засвоєні на попередньому етапі, майбутні вчителі початкової школи безпосередньо формують професійне мовлення: складають конспекти уроків, бесід, планів; аналізують учнівське писемне (зошити, щоденники молодших школярів) й усне (аудіо- та відеозаписи уроків з різних навчальних дисциплін 1-4 класів) мовлення; виразно читають твори різних жанрів тощо. Продовжується робота над виробленням умінь 
складати тексти, ураховуючи адресата спілкування (молодші школярі, батьки, колеги, адміністрація школи тощо), обставини (офіційні/неофіційні) й мету (інформування, переконування, емоційний вплив, спонукання до дії); готувати доповіді для виступів на батьківських зборах, методичних об’єднаннях учителів. Не менш важливою, на нашу думку, є активна педагогічна практика й написання курсових робіт, які логічно завершують цей етап, що дозволяють оцінити значення професійного мовлення майбутнього вчителя початкової школи складника його фахової компетентності.

Заключний етап передбачав узагальнення й осмислення на вищому рівні знань про професійне мовлення, його роль у педагогічній діяльності педагога. Студенти вдосконалюють вироблені на попередніх етапах мовленнєві вміння й навички в процесі виконання складних педагогічних і навчальних завдань. Це залікові уроки з мови й виразного читання, інших дисциплін, проведення різних видів позакласної роботи з молодшими школярами, підготовка виступів перед батьками молодших школярів. Здобувіачі залучаються до участі в проблемних наукових групах, наукових гуртках 3 різних педагогічних, психологічних i методичних проблем; готують тезові повідомлення на наукових і науковопрактичних конференціях; працюють над курсовими й магістерськими (забажанням) роботами. Усе це актуалізує вимоги до професійної культури майбутніх учителів початкової школи.

Отже, аналіз психологічних і лінгводидактичних джерел, а також досвід викладацької роботи на факультеті психолого-педагогічної совіти та мистецтв Бердянського державного педагогічного університету, де готують фахівців спеціальності 013 Початкова освіта, дозволили констатувати необхідність формування професійного мовлення здобувачів вищої освіти як визначального складника їхньої професійної компетентності. Цей процес триває впродовж усього терміну навчання бакалаврату, орієнтовно поділений нами на три етапи: початковий, основний, заключний.

Найбільш вдалим є комунікативно-діяльнісний підхід, який дозволяє не лише збагачувати знання здобувачів, а й формувати необхідні для майбутньої 
професійної діяльності вміння й навички шляхом активного залучення їх до виконання завдань в умовах, максимально наближених до реальних. Саме так можна навчити майбутніх педагогів добирати відповідні мовні засоби, ураховуючи конкретну ситуацію спілкування, адресата, мати й завдань.

Загалом, важливим для нашого експериментального навчання було довести майбутнім учителям початкової школи необхідність постійного вдосконалення професійного мовлення не лише під час фахової підготовки, а й після закінчення навчання у ЗВО. На нашу думку, це актуалізує принципи особистісного й індивідуального підходів у процесі вдосконалення мовленнєвої культури.

Найбільш доцільними формами й методами у формуванні професійного мовлення студентів є проблемні, пошукові, навчально-дослідницькі, інноваційні, тренінгові, метод продукування (комунікативний метод), зокрема такі, що імітують актуальні професійні ситуації, спонукають майбутніх учителів початкової школи контролювати й оцінювати чуже і власне мовлення, активно спиратися самоаналіз і рефлексію, використовувати різні форми співпраці викладача й здобувачів як у навчальній, так і позааудиторній роботі (спілкування за допомогою Інтернет листування), поєднувати групову та індивідуальну роботу. 